\title{
126. 全身振動の音声言語機能におよぼす影響
}

\author{
一一特江語音明瞭度について—
}

\author{
○星 野 健一・横山俊彦*
}

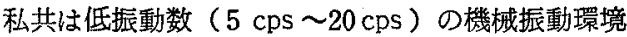
下における Speech Communication の問題をとり あげまずソナグラフおよびブラウン管オシロスコー プを用いて電気音㗽学的に観察した結果を前回の本学 会に報告した。すすなわち振動下の音声は強制振動の周 期一致した顒声様声に变りその周波数成分も高音域に 增大し，音声波形の乱れ，断裂などの变化が生ずるこ とが判つた，今回は振動によつて変調された実験的震 声の語音明瞭度の測定結果, 各実験条件下に扔ける異 聴順向の Confusion matrix 作成に上万観察およ びソナグラフによる視覚的考察を行なつた。

\section{実 医 条件}

負荷振動には $5 \mathrm{cps}(0.6 \mathrm{~g}), 10 \mathrm{cps}(1.2 \mathrm{~g}), 20$ cps (1.2g) の 4 種類を選び, 検查語音には無意味 4 音節語表を作成して用いたが，4 音節中に同種音節 の同時存在, 発語困蜼な音節配列は予め澼けた。発声 者は発語明膫な女性で，振動台上の腰掛䎲正姿勢で坐 り，検査語音も 4 秒間隔で発語せしめ，テープに収録 し，その収録語音は $\mathrm{NHK}$ 大阪中央放送局で，後 2 音 節語の音声音圧が士 $5 \mathrm{~dB}$ 以内になるように調整, 再録音した。受聴者は聴力正常な本学附属厚生学院学 生10名を選び，本学聴力検查室を使用し，録音再生は テープレコーダをオージオメータに接続, 受話器方式 で行なつた。明嘹度測定は非螴音下と騒音下における 検查語音の強さ $65 \mathrm{~dB}, 85 \mathrm{~dB}$ について夷施した。 Masking Noise 亿は白色騷音50 dB，70 dB を用い， 受聴者に 4 音節語の内, 前 2 音節語は聞き流し，後 2 音節語のみを聴取記録するように命じた。

\section{実験結果と考祭}

$70 \mathrm{~dB}$ 白色騒音下での各負荷振動条件下に扝ける 85 $\mathrm{dB}$ と $65 \mathrm{~dB}$ の語音明睽度を観察すると, $85 \mathrm{~dB}$ 語音強 度の場合は負荷振動数が減少するにしたがつてその明 瞭度が非振動下のそれに比べて低下する攧向を示し， $65 \mathrm{~dB}$ 語音強度では $5,10 \mathrm{cps}$ 振動下での語音明瞭度
低下が非振動下の明嘹度よりる著明な低下を来し，そ の低下程度は $85 \mathrm{~dB}$ の場合よりも顕著であつた。しか し $15 \mathrm{cps}$ 振動下の明瞭度は以上の $5,10 \mathrm{cps}$ 振動下の 結果と相反して非振動下の明瞭度よりも明ら加な改善 がみられた。

$65 \mathrm{~dB}$ の語音強度における明瞭度を非騒音下， $50 \mathrm{~dB}$ 騒音下， $70 \mathrm{~dB}$ 歧音下での各負荷振動条件下における それぞれの明瞭度と比較すると（図 1) 非㗨音下にお いても $5 \mathrm{cps}, 10 \mathrm{cps}$ 振動下の明瞭度は非振動下のそ れよりも悪化を示し，その悪化傾向は $50 \mathrm{~dB} ， 70 \mathrm{~dB}$ 臨 音下の順に Masking Noise level の強くなるにつ れて增加している。

つぎに悪化傾向の強い $5 \mathrm{cps}, 10 \mathrm{cps}$ 振動について 図 2 亿示すようにその加速度を減少せしめた負荷振動 条件，すなわち $5 \mathrm{cps}(0.3 \mathrm{~g})$ 扰よ゙ $5 \mathrm{cps}(0.15 \mathrm{~g})$ ), また $10 \mathrm{cps} \quad(0.3 \mathrm{~g}), 10 \mathrm{cps}(0.6 \mathrm{~g})$ のときの明膫 度を $50 \mathrm{~dB} ， 70 \mathrm{~dB}$ 騒音下で測定し锶察すると $50 \mathrm{~dB}$ 騷 音下では有意の差を認めなかつたが，70 dB 疑音下で は $5 \mathrm{cps}(0.3 \mathrm{~g}) ， 5 \mathrm{cps}(0.15 \mathrm{~g}) ， の$ 明瞭度が， また $10 \mathrm{cps}(0.6 \mathrm{~g})$ の明膫度が $5 \mathrm{cps}(0.6 \mathrm{~g}), 10$ $\operatorname{cps}(1.2 \mathrm{~g})$ のときよりも著明な改善を示し，しか も非振動下の明瞭度よりも明らかに上昇を示した。

つぎに如何なる語音か漒制振動によつてどのような

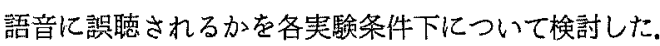
その結果, 負荷振動数によつて特異な誤聴傾向がー部 の語音にみられたが，全般的にみて破裂音，破擦音の ウ列子音に誤聴が多く，濁音化する傾向が顕著であつ た。

これらの点をソナグラフの Contour display およ び pattern 上り分折, 観察した。

上述したように低振動数振動下の語音明膫度は, 負 荷振動数ならびにその強さ，また振動に同時存在する Masking Noise の存在有無扔よびその強さによつて も著明な変化を示すてとを知つた。 


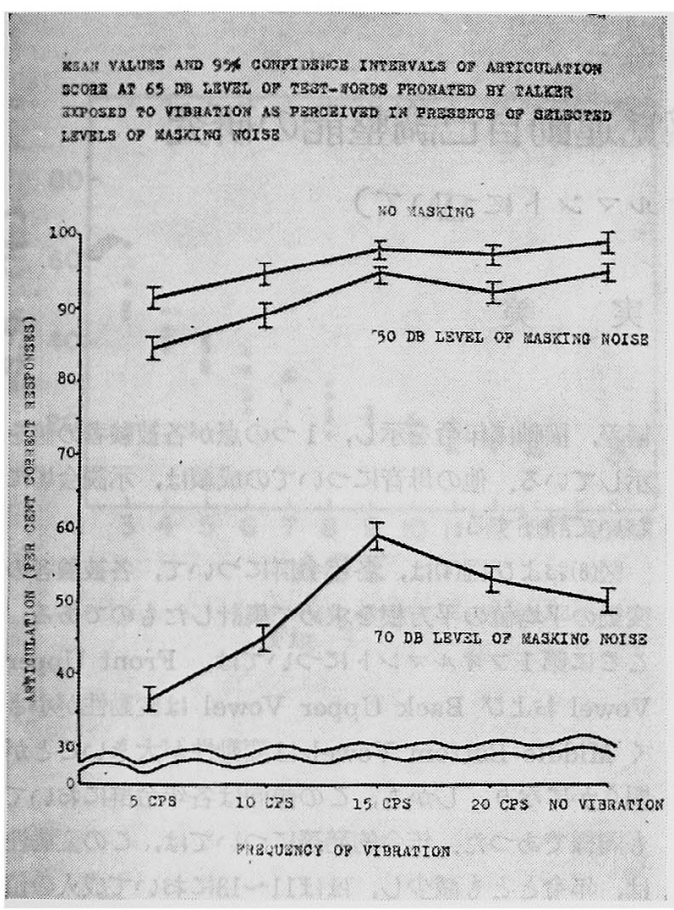

図 1

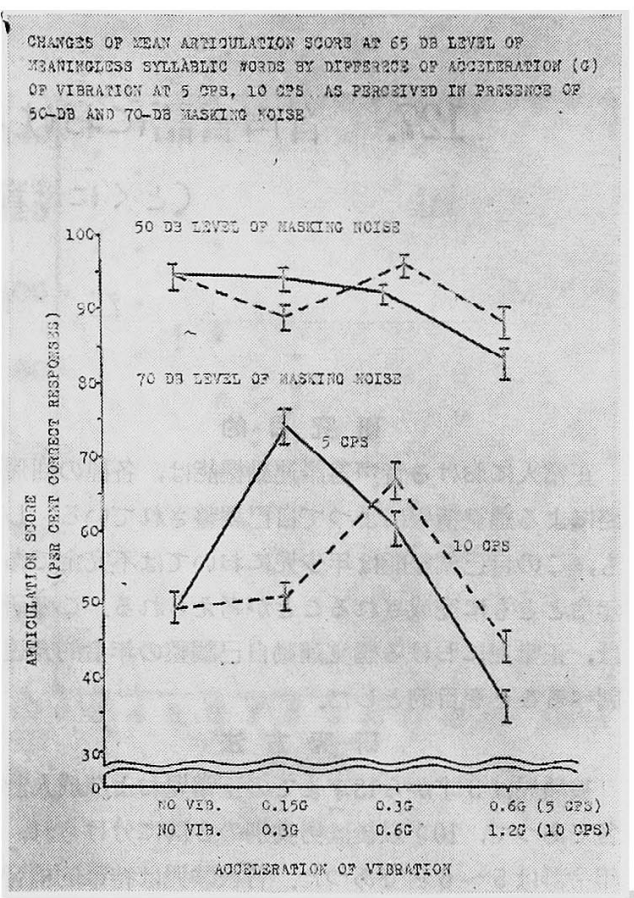

図2 